\title{
Bayesian Survival Analysis Untuk Mengestimasi Parameter Model Weibull-Regression Pada Kasus Ketahanan Hidup Pasien Penderita Jantung Koroner
}

\author{
A. Dewi Lukitasari ${ }^{1}$, Adi Setiawan ${ }^{2}$, Leopoldus Ricky Sasongko ${ }^{3}$ \\ ${ }^{1}$ PS. Matematika, Fakultas Sains dan Matematika, UKSW Salatiga, adewilukitasari@yahoo.com \\ ${ }^{2}$ PS. Matematika, Fakultas Sains dan Matematika, UKSW Salatiga, adi_setia_03@yahoo.com \\ ${ }^{3}$ PS. Matematika, Fakultas Sains dan Matematika, UKSW Salatiga, leopoldus.sasongko@ staff.uksw.edu
}

\begin{abstract}
Abstrak
Paper ini membahas mengenai estimasi parameter model Weibull-Regression untuk data tersensor pada kasus ketahanan hidup pasien penderita jantung koroner dengan pendekatan Bayesian survival analysis. Data yang digunakan adalah data simulasi waktu hidup pasien, status pasien (hidup/mati) dan treatment yang dikenakan yaitu ring dan bypass. Pendekatan Bayesian (Bayesian approach) digunakan untuk mencari distribusi posterior parameter. Metode Markov Chain Monte Carlo $(M C M C)$ digunakan untuk membangkitkan Rantai Markov guna mengestimasi parameter meliputi koefisien regresi $(\beta)$ dan parameter $r$ dari model survival Weibull. Parameter $\beta$ dan $r$ yang diperoleh digunakan untuk menghitung fungsi survival tiap pasien untuk tiap treatment yang sekaligus menunjukkan probabilitas bertahan hidup pasien penderita jantung koroner.
\end{abstract}

Kata Kunci : Bayesian, Markov Chain Monte Carlo (MCMC), Model Weibull-Regression, Survival Analysis

\section{Bayesian Survival Analysis for Estimating Parameters Weibull-Regression Model In Case Resilient Life Patients with Coronary Heart Disease}

\section{Abstract}

This paper discusses the estimation of model parameter Weibull-Regression to the data censored in case of survival of patients with coronary heart disease with survival analysis Bayesian approach. The data used is the simulation time of life of patients, patient status (live/die) and subjected to treatment that ring and bypass. Bayesian approach (Bayesian approach) is used to find the posterior distribution of the parameters. Methods of Markov Chain Monte Carlo (MCMC) used to generate the Markov chain to estimate the parameters include regression coefficient $(\beta)$ and $r$ parameters of Weibull survival models. $\beta$ and $r$ parameters obtained are used to calculate the survival function for each treatment for each patient that shows the probability of survival of patients with coronary heart disease.

Keywords: Bayesian, Markov Chain Monte Carlo (MCMC), Weibull-Regression Models, Survival Analysis

\section{Pendahuluan}

Pada makalah [1] telah dibahas cara mengestimasi parameter model Cox-Regression pada kasus ketahanan hidup pasien penderita jantung koroner[1]. Permodelan data survival dengan menggunakan Bayesian survival analysis menggunakan Cox-Regression tidak memperhatikan adanya data tersensor. Kenyataannya, selama proses pengamatan berlangsung terdapat data tersensor (censored data) yaitu data yang tidak terobservasi secara penuh (not completely observable) dalam waktu pengamatan [2]. Hal ini berarti selama proses pengamatan dalam rentang waktu yang ditentukan, terdapat pasien yang belum selesai menjalani treatment dan waktu hidupnya tetap dicatat dalam pengamatan. Oleh karena itu untuk mengolah data tersensor digunakan analisis model survival parametrik. Model yang sering digunakan adalah model Weibull[2]. Distribusi Weibull digunakan secara efektif untuk menganalisis data waktu hidup khususnya untuk data tersensor [3]. Fungsi survival distribusi Weibull diestimasi dan digunakan sebagai distribusi probabilitas untuk data waktu bertahan hidup pasien penderita jantung koroner. Diasumsikan data yang digunakan termasuk ke dalam Random Censoring. 


\section{Dasar Teori}

\subsection{Data Tersensor}

Data tersensor adalah data yang tidak teramati secara penuh (not completely observable). Biasanya data tersensor ini dijumpai untuk studi observasi dan penelitian dengan adanya batasan waktu.Terdapat 3 tipe data tersensor yaitu Tersensor tipe I, Tersensor tipe II dan Random Censoring. Data tersensor tipe I terjadi apabila subjek berhenti sebelum pemberian waktu sensor. Data tersensor tipe II terjadi apabila subjek melampaui batas waktu pengamatan dan waktu survivenya catat jika subjek telah mengalami kegagalan. Random Censoring adalah tipe data tersensor yang sering terjadi [2].

\subsection{Distribusi Weibull}

Distribusi Weibull merupakan distribusi yang sering digunakan dalam analisis parametrik untuk fungsi survival. Distibusi Weibull banyak digunakan pada aplikasi di bidang industri maupun biomedis. Realitas yang ditemui untuk bidang engineering digunakan untuk menggambarkan waktu kegagalan (time to failure) pada barang elektronik dan sistem mekanikserta untuk memodelkan ketahanan barang elektronik [3]. Secara umum fungsi kepadatan probabilitas (probabilitydensity function) dari distribusi Weibull adalah:

$$
f(t)=\frac{r}{\theta^{r}} t^{r-1} \exp \left[-\left(\frac{t}{\theta}\right)^{r}\right] \text { dengan } r, \theta>0 \text { dan } t \geq 0
$$

Dengan mensubtitusikan $\lambda=\left(\frac{1}{\theta}\right)^{r}$ ke dalam persamaan (1) maka diperoleh :

$$
f(t)=r \lambda t^{r-1} \exp \left(-\lambda t^{r}\right)
$$

Shape parameter dan scale parameter berurutan ditunjukkan oleh nilai $r$ dan $\theta$. Scale parameter (parameter skala) adalah jenis khusus dari parameter numerik yang menunjukkan besarnya distribusi data. Semakin kecil nilai dari scale arameter maka distribusi data akan menyebar. Scale parameter (parameter bentuk) adalah jenis khusus dari parameter numerik yang menunjukkan bentuk dari kurva. Fungsi survival untuk distribusi Weibull dapat diperoleh dengan mengintegralkan fungsi kepadatan probabilitas pada persamaan (1) sehingga

$$
S(t)=\int_{t}^{\infty} f(u) d u=\exp \left(-\lambda t^{r}\right)
$$

Laju kegagalan pasien ditunjukkan oleh fungsi hazard (hazard function) dari distribusi Weibull yaitu:

$$
\lambda_{0}(t)=\frac{f(t)}{S(t)}=\frac{d}{d t} \ln S(t)=r \lambda t^{r-1} .
$$

Fungsi hazard kumulatifnya (cumulative hazard function) ditunjukkan seperti berikut [4]:

$$
\Lambda_{0}(t)=\int_{0}^{t} \lambda_{0}(u) d u=\lambda t^{r}
$$

\subsection{Weibull-Regression}

Model regresi Weibull untuk distribusi dari fungsi survival dapat dirumuskan sebagai berikut:

$$
f\left(t_{i}, z_{i}\right)=r e^{\beta^{\prime} z_{i}} t_{i}^{r-1} \exp \left(-e^{\beta^{\prime} z_{i}} t_{i}^{r}\right)
$$

dengan mengganti $\mu_{i}=e^{\beta^{\prime} z_{i}}$ maka persamaan (6) berubah menjadi:

$$
f\left(t_{i}, \mu_{i}\right)=r \mu_{i} t_{i}^{r-1} \exp \left(-\mu_{i} t_{i}^{r}\right)
$$

dengan $t_{i}$ menunjukkan waktu bertahan hidup untuk data pasien yang tersensor dengan vektor covariate $z_{i}$ [5]. Dalam hal ini $r$ sebagai parameter yang akan diestimasi nilainya. Distribusi 
Weibull digunakan karena fleksibel meliputi bentuk dan model sederhana yang memungkinkan perubahan kenaikan $r>1$, penurunan $r<1$ dan laju kegagalan yang konstan untuk $r=1$ [6]. Koefisien regresi dari model Weibull adalah $\beta$ yang diperoleh dengan mengasumsikannya sebagai prior yang berdistribusi normal $\beta \sim N(0,0.0001)$. Parameterisasinya $T_{i} \sim \operatorname{Weibull}\left(r_{i}, \mu_{i}\right)$.

\subsection{Distribusi Prior Model Weibull}

Penentuan distribusi prior model Weibull ditentukan dengan mengambil distribusi yang sering digunakan sebagai standar yaitu Normal $N\left(0, \sigma^{2}\right)$ dengan nilai $\sigma^{2}$ diambil nilai 0.0001 sebagai vague precision untuk model regresi Weibull. Penentuan distribusi Prior untuk penentuan shape parameter $r$ menggunakan distribusi Gamma $(1,0.0001)$ untuk fungsi distribusi survival yang turun perlahan pada saat nilai $t \geq 0$ (positive real line)[5].

\subsection{Fungsi Likelihood Model Weibull}

Fungsi likelihood yang biasa digunakan untuk menganalisis data tersensor adalah

$$
L(D \mid r, \beta)=\prod_{i=1}^{n} f\left(t_{i}\right)^{\delta_{i}}\left[S\left(t_{i}\right)\right]^{\left(1-\delta_{i}\right)} .
$$

Dengan mensubtitusikan $f\left(t_{i}\right)$ diberikan pada persamaan (2) dan $S\left(t_{i}\right)$ pada persamaan (3)maka diperoleh fungsi likelihood untuk Model Weibull yaitu:

$$
L(D \mid r, \beta)=\prod_{i=1}^{n}\left[r e^{\beta^{\prime} z_{i}} t_{i}^{r-1} \exp \left(-e^{\beta^{\prime} z_{i}} t_{i}^{r}\right)\right]^{\delta_{i}}\left[\exp \left(-\lambda t^{r}\right)\right]^{\left(1-\delta_{i}\right)}
$$

dengan $\delta_{i}=0$ jika observasi ke- $i$ tersensor dan $\delta_{i}=1$ jika observasi ke- $i$ tidak tersensor [2].

\subsection{Aproksimasi Distribusi Posterior}

Dalam estimasi Bayes, setelah informasi tentang sampel dan prior dapat ditentukan maka distribusi posteriornya dicari dengan cara mengalikan priornya dengan informasi sampel yang diperoleh dari likelihoodnya [7]. Dituliskan sebagai berikut:

$$
P(r, \beta \mid D) \propto L(D \mid r, \beta) P(r) P(\beta) .
$$

Akan difokuskan dalam mengestimasi parameter $r$ dan $\beta$. Karena model rumit karena mengandung banyak parameter makadistribusi posterior susah untuk diestimasi secara langsung, maka perlu adanya suatu pendekatan menggunakan metode simulasi dengan MCMC (Markov Chain Monte Carlo). Pada proses MCMC dipilih menggunakan algoritma Gibbs Sampling.

Algoritma Gibbs Sampling dalam winBUGS membutuhkan nilai awal dari parameter yang akan di estimasi. Nilai awal ditentukan yaitu $\beta \sim \operatorname{Normal}(0,0.0001)$ dan $r \sim \operatorname{Gamma}(1,0.0001)$ Langkah manual penyusunan algoritma Gibbs Sampling dibuat dengan prosedur penentuan $(P(r \mid D, \beta), P(r \mid D, \beta))$ dengan langkah pada persamaan (11) dan (12) yaitu:

$$
P(\beta \mid D, r) \propto P(\beta) L(D \mid r, \beta)
$$

dan

$$
P(r \mid D, \beta) \propto P(r) L(D \mid r, \beta) .
$$

Langkah pada persamaan (11) dan (12) diulang sebanyak bilangan $\beta$ yang cukup besar, dengan $\beta$ merupakan banyaknya update pada software WinBUGS 1.4 yaitu proses iterasi guna menyusun rantai Markov hingga diperoleh deret rantai Markov yang konvergen. 


\section{METODE PENELITIAN}

\subsection{Profil data}

Data yang digunakan adalah data waktu bertahan hidup, status hidup pasien dan treatment yang digunakan pasien penderita jantung koroner[4]. Kemudian dilakukan simulasi dengan menambah data yang tersensor. Data survival ditunjukkan pada Tabel 1 dengan banyaknya pasien sejumlah 40 pasien dan dua treatment yang dikenakan yaitu treatment Ring dan Bypass.Dalam hal ini tanda * menunjukkan data yang tersensor. Banyaknya data yang tersensor untuk treatment Ring sebanyak 1 pasien dan untuk treatment Bypass sebanyak 7 pasien. Status hidup pasien bernilai 0 menunjukkan pasien tetap bertahan hidup saat menjalani treatment dan bernilai 1 menunjukkan pasien meninggal saat proses treatment berlangsung.

\subsection{Langkah-langkah Penelitian}

Pengolahan data dengan menggunakan winBUGS 1.4. Sspesifikasi model meliputi pengecekan terhadap syntax model, loading data, compiling model, inisialisasi model, menentukan iterasi MCMC sebanyak 200.000 kali guna membangkitkan Rantai-Markov hingga mencapai konvergen. Parameter yang akan diestimasi meliputi treatment ring, bypass serta parameter distribusi Weibull $r$. Updating data parameter ditentukan sebanyak 200.000 titik sampel. Dalam ploting masing-masing node dan parameter beta nilai rantai Markov dilakukan burn in sebanyak 100.000 data, dan diambil bangkitan rantai dari data ke 100.001 sampai dengan 200.000 titik sampel.

Tabel 1. Data survival pasien penderita jantung koroner

\begin{tabular}{|c|c|c|c|c|c|c|c|}
\hline No & $\begin{array}{c}\text { Waktu } \\
\text { (bulan) }\end{array}$ & Status & Treatment & No & $\begin{array}{c}\text { Waktu } \\
\text { (bulan) }\end{array}$ & Status & Treatment \\
\hline 1 & 26 & 0 & Ring & 21 & 32 & 0 & Bypass \\
\hline 2 & 26 & 0 & Ring & 22 & 33 & 0 & Bypass \\
\hline 3 & 38 & 0 & Ring & 23 & 42 & 0 & Bypass \\
\hline 4 & 51 & 0 & Ring & 24 & 42 & 0 & Bypass \\
\hline 5 & 52 & 0 & Ring & 25 & 56 & 0 & Bypass \\
\hline 6 & 56 & 0 & Ring & 26 & $56^{*}$ & 0 & Bypass \\
\hline 7 & 57 & 0 & Ring & 27 & $60^{*}$ & 1 & Bypass \\
\hline 8 & 61 & 1 & Ring & 28 & 65 & 0 & Bypass \\
\hline 9 & 62 & 0 & Ring & 29 & 78 & 0 & Bypass \\
\hline 10 & 62 & 0 & Ring & 30 & 87 & 0 & Bypass \\
\hline 11 & 66 & 0 & Ring & 31 & $87^{*}$ & 0 & Bypass \\
\hline 12 & 71 & 1 & Ring & 32 & 93 & 0 & Bypass \\
\hline 13 & 71 & 0 & Ring & 33 & $102^{*}$ & 0 & Bypass \\
\hline 14 & 75 & 0 & Ring & 34 & $116^{*}$ & 0 & Bypass \\
\hline 15 & 83 & 0 & Ring & 35 & $116^{*}$ & 1 & Bypass \\
\hline 16 & 106 & 0 & Ring & 36 & $146^{*}$ & 1 & Bypass \\
\hline 17 & 123 & 0 & Ring & 37 & 161 & 0 & Bypass \\
\hline 18 & $128^{*}$ & 0 & Ring & 38 & 173 & 1 & Bypass \\
\hline 19 & 156 & 0 & Ring & 39 & 178 & 1 & Bypass \\
\hline 20 & 183 & 0 & Ring & 40 & 182 & 1 & Bypass \\
\hline
\end{tabular}

\section{Hasil dan Pembahasan}

Dalam proses analisis data yang terdiri dari $N=40$ dan $M=2$, dengan $N$ menyatakan total pasien penderita penyakit jantung koroner dan $M$ menunjukkan banyaknya treatment yang digunakan oleh pasien meliputi metode pengobatan Ring dan Bypass. 
Weibull-Regresionmenggunakan pendekatan Bayesian dilakukan dengan update untuk menyusun MCMC dengan iterasi sebanyak 200.000 titik sampel. Hasil nilai estimasi dan karakteristik untuk masing-masing parameter ditunjukkan pada Tabel 2 dan Tabel 3.

Tabel 2. Hasil estimasi Bayesian untuk parameter $\beta$ node Ring dan Bypass

\begin{tabular}{|c|c|c|c|c|c|c|}
\hline Node & Mean & $\begin{array}{c}\text { Standard } \\
\text { Deviasi }\end{array}$ & $\begin{array}{c}\text { MC } \\
\text { error }\end{array}$ & $\begin{array}{c}\text { Batas minimum } \\
\mathbf{2 , 5 \%}\end{array}$ & Median & $\begin{array}{c}\text { Batas maksimum } \\
\mathbf{9 7 , 5 \%}\end{array}$ \\
\hline Ring & $\mathbf{- 8 . 9 3 6}$ & 1.248 & 0.02904 & -11.51 & -8.889 & -6.627 \\
\hline Bypass & $\mathbf{- 0 . 7 8 6 8}$ & 0.3685 & 0.00155 & -1.524 & -0.7821 & -0.07581 \\
\hline
\end{tabular}

Tabel 3. Hasil estimasi Bayesian untuk parameter $\boldsymbol{r}$

\begin{tabular}{|c|c|c|c|c|c|c|}
\hline Node & Mean & $\begin{array}{c}\text { Standard } \\
\text { Deviasi }\end{array}$ & $\begin{array}{c}\text { MC } \\
\text { error }\end{array}$ & $\begin{array}{c}\text { Batas Minimum } \\
\mathbf{2 , 5 \%}\end{array}$ & Median & $\begin{array}{c}\text { Batas Maksimum } \\
\mathbf{9 7 , 5 \%}\end{array}$ \\
\hline$r$ & $\mathbf{1 . 9 8}$ & 0.2609 & 0.00612 & 1.493 & 1.972 & 2.515 \\
\hline
\end{tabular}

Tabel 4. Probabilitas tiap pasien untuk masing-masing treatment

\begin{tabular}{|c|c|c|c|c|c|c|c|}
\hline No & $\begin{array}{l}\text { Waktu } \\
\text { (bulan) }\end{array}$ & $\mathbf{S}(\mathbf{t})$ & Treatment & No & $\begin{array}{r}\text { Waktu } \\
\text { (bulan) }\end{array}$ & $\begin{array}{c}\mathbf{S}(\mathbf{t}) \\
1 \times 10^{-125}\end{array}$ & Treatment \\
\hline 1 & 26 & 0.9200 & Ring & 21 & 32 & 0.5810 & Bypass \\
\hline 2 & 26 & 0.9200 & Ring & 22 & 33 & 0.5810 & Bypass \\
\hline 3 & 38 & 0.8381 & Ring & 23 & 42 & 0 & Bypass \\
\hline 4 & 51 & 0.7288 & Ring & 24 & 42 & 0 & Bypass \\
\hline 5 & 52 & 0.7198 & Ring & 25 & 56 & 0 & Bypass \\
\hline 6 & 56 & 0.6834 & Ring & 26 & $56^{*}$ & 0 & Bypass \\
\hline 7 & 57 & 0.6742 & Ring & 27 & $60 *$ & 0 & Bypass \\
\hline 8 & 61 & 0.6370 & Ring & 28 & 65 & 0 & Bypass \\
\hline 9 & 62 & 0.6277 & Ring & 29 & 78 & 0 & Bypass \\
\hline 10 & 62 & 0.6277 & Ring & 30 & 87 & 0 & Bypass \\
\hline 11 & 66 & 0.5904 & Ring & 31 & $87 *$ & 0 & Bypass \\
\hline 12 & 71 & 0.5439 & Ring & 32 & 93 & 0 & Bypass \\
\hline 13 & 71 & 0.5439 & Ring & 33 & $102 *$ & 0 & Bypass \\
\hline 14 & 75 & 0.5072 & Ring & 34 & $116^{*}$ & 0 & Bypass \\
\hline 15 & 83 & 0.4362 & Ring & 35 & $116^{*}$ & 0 & Bypass \\
\hline 16 & 106 & 0.2601 & Ring & 36 & $146^{*}$ & 0 & Bypass \\
\hline 17 & 123 & 0.1640 & Ring & 37 & 161 & 0 & Bypass \\
\hline 18 & $128 *$ & 0.1414 & Ring & 38 & 173 & 0 & Bypass \\
\hline 19 & 156 & 0.0553 & Ring & 39 & 178 & 0 & Bypass \\
\hline 20 & 183 & 0.0189 & Ring & 40 & 182 & 0 & Bypass \\
\hline
\end{tabular}

Pada [1] telah diperoleh satu nilai estimasi parameter $\beta$ model Cox-Regression untuk kedua teknik pengobatan Ring dan Bypass yaitu sebesar -0.8789 [1]. Pada model WeibullRegression didapatkan dua nilai parameter $\beta$ untuk treatment Ring dan Bypass berurutan sebesar -8.936 dan -0.7868. Probabilitas tiap pasien untuk masing-masing treatment ditunjukkan pada Tabel 4. Nilai probabiitas tertinggi untuk pasien menggunakan treatment Ring adalah 0.9200 dan yang terendah adalah 0.0189. Sedangkan untuk treatment bypass diperoleh nilai probabilitas yang sangat kecil. Pebandingan nilai probabilitas ketahanan hidup pasien penderita jantung koroner untuk model Cox-Regression dan Weibull-Regression ditunjukkan pada Tabel 5. Dari Tabel 5 terlihat nilai probabilitas bertahan hidup pasien dengan menggunakan Weibull-Regression jauh lebih kecil jika dibandingkan dengan model Cox-Regression. Nilai probabilitas fungsi survival yang bernilai 0 diduga karena model Weibull-Regression kurang sesuai untuk mengestimasi parameter ketahanan hidup pasien penderita jantung koroner. 
Tabel 5. Probabilitas survivaluntuk model Cox-Regression dan Weibull-Regression

\begin{tabular}{|c|c|c|c|c|}
\hline Pasien ke - & $\begin{array}{c}\text { Waktu } \\
\text { (bulan) }\end{array}$ & $\begin{array}{c}\text { S(t) } \\
\text { Cox-Regression }\end{array}$ & $\begin{array}{c}\text { S(t) } \\
\text { Weibull-Regression }\end{array}$ & $\begin{array}{c}\text { Status } \\
\text { Pasien }\end{array}$ \\
\hline 8 & 61 & 0.9771 & 0.6370 & 1 \\
\hline 12 & 71 & 0.9536 & 0.5439 & 1 \\
\hline 27 & 60 & 0.9262 & 0 & 1 \\
\hline 35 & 116 & 0.8781 & 0 & 1 \\
\hline 36 & 146 & 0.8119 & 0 & 1 \\
\hline 38 & 173 & 0.7185 & 0 & 1 \\
\hline 39 & 178 & 0.6130 & 0 & 1 \\
\hline 40 & 182 & 0.4868 & & \\
\hline
\end{tabular}

Mean dan Median dalam Tabel 2 menunjukkan nilai estimasi titik untuk nilai parameter $\beta$. Rata-rata dari parameter dalam Tabel 2 merepresentasikan estimasi nilai rata-rata posterior untuk pasien yang menggunakan ring dan bypass menggunakan kedua treatment tersebut. Nilai mean untuk pasien dengan ring adalah -8.936 sedangkan dengan bypass -0.7868 . Nilai error dalam penyusunan MCMC dengan algoritma Gibbs Sampling ditunjukkan dari MC error, diperoleh nilai erroryang cukup kecil karena mendekati nol. Estimator interval untuk parameter ditunjukkan dari interval konfidensi yakni batas minimum dan maksimum dengan pengambilan nilai $\alpha=0,5$. Estimasi parameter menunjukkan bahwa semua parameter terletak dalam batas interval konfidensi pada posisi antara $2,50 \%$ dan $97,50 \%$ dan nilainya signifikan karena tidak melewati nilai nol. Adanya interval konfidensi tersebut menjamin pencakupan dari parameter yang diselidiki. Nilai dari koefisien regresi $\beta$ ditunjukkan dari nilai mean dari ring dan bypass.

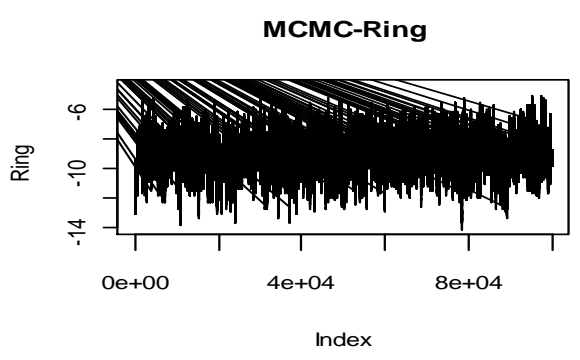

MCMC-Bypass

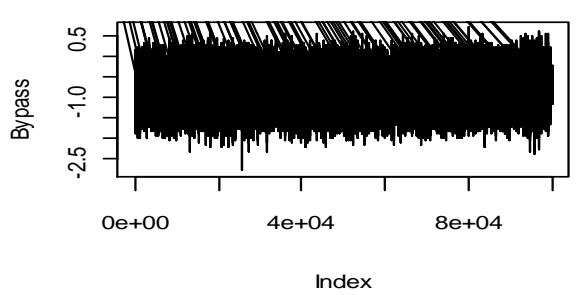

MCMC-r

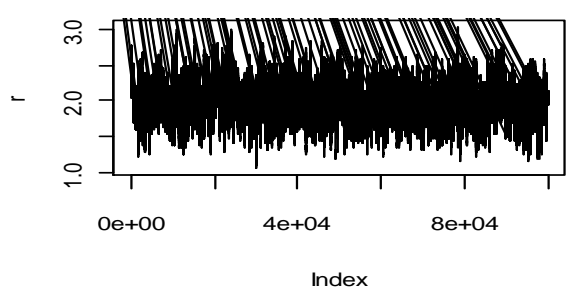

Densitas Kernel beta-Ring

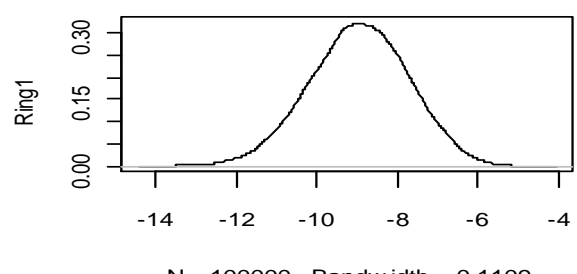

$\mathrm{N}=100000 \quad$ Bandw idth $=0.1109$

Densitas Kernel beta-Bypass

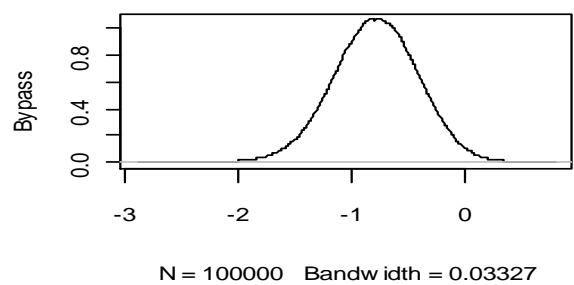

Densitas Kernel-r

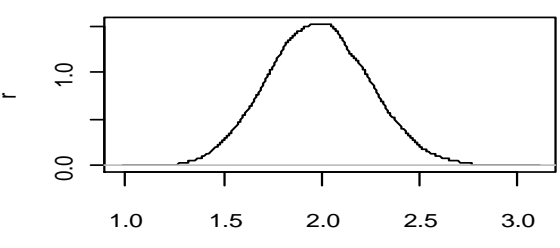

$N=100000 \quad$ Bandw idth $=0.02319$

Gambar 1. Plotime series untuk MCMC Bayesian dan densitas kernel node Ring, node Bypass, dan $r$ 
Plot time series untuk MCMC Bayesian dan densitas kernel ditujukkan dalam Gambar 1. Plot dari time series menunjukkan gambaran rantai Markov yang dibangkitkan dari data dengan updating sebanyak 200.000 iterasi.

Plot Gambar 1. menunjukkan nilai MCMC tidak selalu positif, hasil plot nampak rapat dan dapat merespon keseluruhan sampel berarti didapati model telah konvergen. Nilai estimasi densitas posterior dapat dilihat dari plot densitas kernel. Estimasi densitas kernel memberikan plot yang bagus karena dihasilkan densitas yang cenderung halus. Plot dari densitas kernel untuk setiap node Ring dan Bypass mengikuti densitas prior yakni berdistribusi normal sedangkan untuk parameter $r$ juga cenderung normal. Gambaran MCMC mengindikasikan bahwa nilai yang ditunjukkan berasal dari sebaran posterior yang dibentuk oleh rantai Markov.

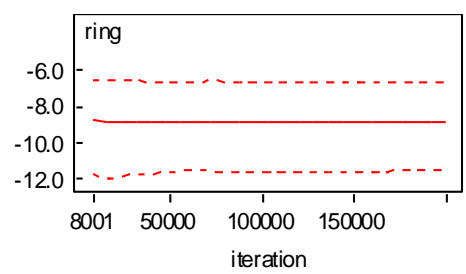

Series ring[100001:2e+05]

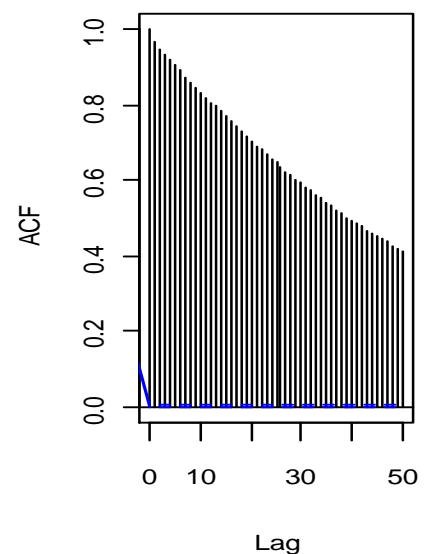

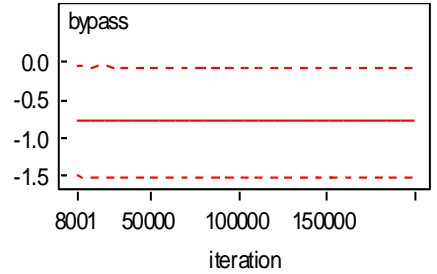

Series bypass[100001:2e+0

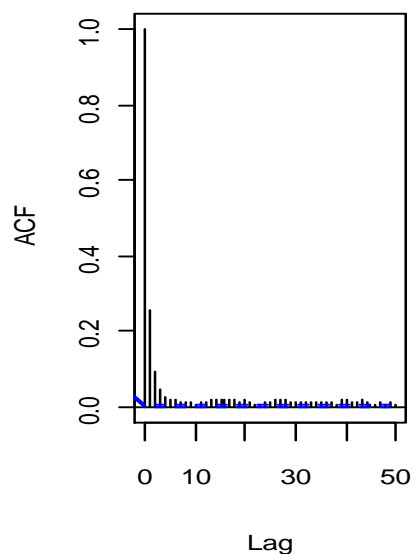

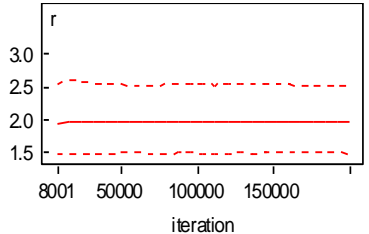

Series r[100001:2e+05]

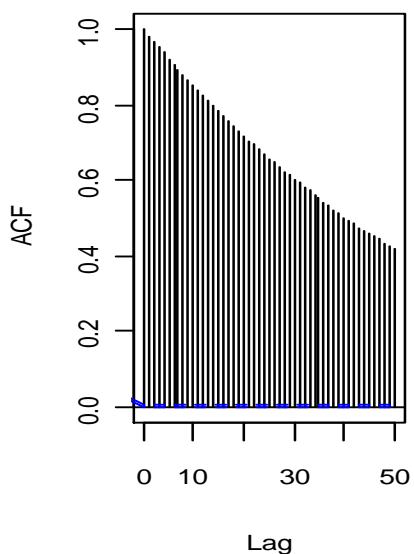

Gambar 3. Gambaran running quantiles dan autokorelasi

Gambar 3. menunjukkan plot dari running quantilesyang merepresentasikan gambaran mengenai nilai dari kinerja sampel yang cukup bagus. Hal tersebut ditunjukkan dari posisi plot garis yang masih terletak di dalam rentang interval yaitu diantara batas atas dan bawah. Gambaran nilai autokorelasi untuk tiap node dan parameter ditunjukkan pula pada Gambar 3. Nilai autokorelasi menunjukkan bahwa data yang dibangkitkan memenuhi sifar rantai Markov [8].Plot nilai autokorelasi dengan menggunakan fungsi acf pada $\mathrm{R}$ i386 3.0.1.ACF merupakan singkatan dari Auto Corelation Function. Nilai autokorelasi untuk ring dan $r$ kuat ditunjukkan dari plot autokorelasi yang turun secra perlahanan, Sedangkan untuk node bypass tidak sekuat nilai autokorelasi untuk ring dan $r$. Hal tersebut terlihat dari plot autokorelasi yangturun tajam.

Berdasarkan analisis yang dilakukan diperoleh nilai estimasi parameter $\beta$ dan $r$ dari model Weibull-Regresion untuk pasien penderita jantung koroner.

\section{Kesimpulan}

Dalam paper ini diperoleh nilai parameter $\beta$ dan $r$ serta nilai probabilitas bertahan hidup pada model Weibull-Regression untuk mengolah data tersensor ketahanan hidup pasien penderita jantung koroner denganBayesian survival analysis. 


\section{Daftar Pustaka}

[1] Lukitasari,A.D., A. Setiawan dan L. R. Sasongko. 2014. Bayesian Survival Analysis menggunakan Cox-Regression untuk Mengestimasi Model Ketahanan Hidup Pasien Penderita Jantung Koroner. Prosiding Seminar Nasional Sains dan Pendidikan Sains. Universitas Muhammadiyah : Purworejo.

[2] Perra, S. 2013. Objective Bayesian Variable Selection for Censored Data. Fakultas Matematika dan Informatika. Universitas Cagliari: Italia.

[3] Klein, J.P dan M.L. Moeschberger. 1997. Survival Analysis : Techniques for Censored and Truncated Data. New York. Springer-Verlag New York Inc.

[4] Hendrajaya, Y., A. Setiawan dan H.A. Parhusip. 2008. Penerapan Analisis Survival untuk Menaksir Waktu Bertahan Hidup bagi Penderita Penyakit Jantung. Program Studi Matematika. Fakultas Sains dan Matematika. UKSW : Salatiga.

[5] Long, A.E. 1999. Weibull Regression in Censored Survival Analysis. http://users.aims.ac.za/ mackay/BUGS/Manual05/Examples1/node27.html [16 Desember 2014]

[6] Thamrin, S.A. 2013. Bayesian Survival Analysis Using Gene Expression.Fakultas Sains dan Teknik. Universitas Teknologi Queensland : Australia.

[7] Subanar.2013.Statistika Matematika.Graha Ilmu: Yogyakarta.

[8] Hidayah,E. 2013. Model Disagregasi Data Hujan Temporal dengan Pendekatan Bayesian sebagai Input Permodelan Banjir. ITS:Surabaya.

[9] Candra S.A. 2011. Inferensi Statistik Distribusi Binomial Dengan Metode Bayes Menggunakan Prior Konjugat. Universitas Diponegoro: Semarang.

http://eprints.undip.ac.id/29153/1/ade candra.pdf

[10] Rahayu, N., A. Setiawan, T. Mahatma. 2013. Analisis Regresi Cox Proporsional Hazards pada Ketahanan Hidup Pasien Diabetes Mellitus. Program Studi Matematika. Fakultas Sains dan Matematika. UKSW : Salatiga.

[11] London, DFSA. 1997.Survival Model and Their Estimation. ACTEX Publication : USA.

[12] Mustafa, A. dan A. B. Ghorbal. 2011. Using WinBUGS to Cox Model with Changing from the Baseline Hazard Function. Fakultas Matematika. Universitas Islam Al-Imam Muhammad Ibn Saud : Saudi Arabia. 